\author{
Милица Обреновић \\ Универзитет у Београду \\ Филолошки факултет
}

821.521.09-31 Murakami H https://doi.org/10.18485/filkult.2016.2.ch13

\title{
ПОТРЕБА ЗА ПРИПАДАЮЕМ И ДОДИРОМ РУКЕ НАСУПРОТ УСАМЉЕНОСТИ У РОМАНИМА ХАРУКИЈА МУРАКАМИЈА
}

\section{Сажетак}

Овај рад бави се анализом ликова Харукија Муракамија који живе у савременом, модерном јапанском друштву, често отуђени једни од других. Тема је свевремена. Анализом мотива потребе за припадањем, додира и усамљености, прелазе се географске, националне и културолошке границе, али и странице једног романа, јер поменути мотиви представљају обележја сваког човека, са истим унутрашњним потребама и страховима, ма где и ма када живео.

Већина ликова које Мураками ствара често проводе време у осами, осећајући се прилично сигурно, готово задовољни сами са собом у друштву. Па ипак, даљом и дубљом анализом и женских и мушких ликова, запажамо да потајно жуде за блискошћу и припадањем некоме. Остварајући блискост са другом особом, они проналазе део себе.

Независно од тога да ли је реч о мушком или о женском лику, Мураками се посредно бави аспектом везе и поновног повезивања са људима око нас, али и са нама самима. Он посредно говори о монотонији савременог друштва освешћујући њено постојање на начин којим заокупљује његове ликове и отуђује их једне од других, али и од себе самих.

Кључне речи: припадање, додир руке, усамљеност, блискост, подршка, разумевање, сигурност.

\section{Увод}

Ерих Фром у својој књизи Здраво друштво наводи да је: „отуђени човек несрећан“ (95), што представља главни мотив којим 
можемо да почнемо овај рад, а показаћемо да је полазиште уједно и закључак којим ћемо да завршимо овај рад. У једној другој својој књизи Бекство од слободе, Ерих Фром, говорећи о идентитету појединца у модерном друштву, напомиње да је нови индустријски систем развио појединца, али да га је учинио беспомоћним, да је повећао слободу, али да је створио нове зависне односе, као и да: „... структура модерног друштва делује на човека двојако: он постаје независнији, самопоузданији и критичнији, а постаје и издвојенији, усамљенији и застрашенији“ (78).

Све претходно наведено односи се и на Муракамијеве ликове, то јест, могли бисмо рећи да је такво виђење човека свевремено. Муракамијеви ликови теже љубави, имају потребу за припадањем и додиром руке, свесно, несвесно или подсвесно.

О губитку идентитета и несналажењу у модерном друштву, Карл Густав Јунг у својој књизи Човек и његови симболи наводи следеће: „Нема сумње да чак ни на нивоу који називамо високим степеном цивилизације људска свест није достигла разумни степен постојаности. Још увек је рањива и подложна одроњавању“ (20).

У романима Харукија Муракамија, као један од мотива, увиђамо мотив додира руке. Насупрот њему, издваја се мотив усамљености. Мотив усамљености издваја се кроз приказ савременог јапанског друштва, али и друштва уопште, не само јапанског.

Харуки Мураками пружа нам свет „бљештавила“ модерног друштва у ком осамљени и усамљени живе његови ликови. Његови ликови нису усамљени у свом осећању.

Наиме, тако се осећа човек данашњице, независно од друштва у ком живи и нације којој припада.

Бљештавило модерног друштва гаси светло у животу појединца. Глобализација, брза, лака и стална доступност информација и олакшано успостављање везе међу људима, можда наизглед парадоксално, чини да је човек усамљенији и да теже успоставља праве везе. Модерно друштво и његове тековине замењују додир руке виртуелним додиром, то јест, доносе одсуство емоција и осећаја припадности и прихваћености. Везе које се успостављају површне су и пролазне.

Са тиме се срећемо у романима Харукија Муракамија, свевременом темом која у својој основи заокупља човечанство од дав- 
нина, о којој је говорио Серен Кјеркегор, дански филозоф у 19. веку описујући човека као „...беспомоћног појединца ког раздиру и муче сумње, кога опхрвава осећање усамљености и безначајности“ (цит. према Fromm 97).

Иако се Муракамију често приписује наклоност ка западњачкој култури, јер, између осталог, користи обележја, наизглед, искључиво америчког друштва, Харуки Мураками на званичној веб страници, одговарајући на питања у вези са романом Кафка на обали мора, објашњава да када пише роман, он укључи све информације које постоје у њему, а то може да буде и јапанска и западњачка информација између којих он не прави разлику. Наиме, Мураками сматра да пише о Јапанцима какви они заиста јесу. Њихово понашање, реакције и размишљања су веома јапанска. Он, у интервјуу који је дао Џону Реју, наводи да готово ниједан јапански читалац нема замерку на његов опис њих, то јест да се његове приче разликују од њихових живота. Ми, као припадници неке друге културе и другачијег животног окружења, не осећамо препреке и не примећујемо разлике приликом сусрета са Муракамијевим стваралаштвом и његовим описима Јапанаца. Штавише, осећамо припадност и поиствећујемо се са оним што нас чини људима, са истим проблемима, сумњама и унутрашњим борбама, ма где и ма када живели.

Породица, у традиционалној јапанској књижевности, имала је превише значајну улогу, речи су Муракамија у интервјуу који је дао Џону Реју, а он је желео да прикаже свог главног лика као независног, апсолутног појединца. Његов статус становника града има везе са тим. Он је тип мушкарца који бира слободу и усамљеност уместо интимности, личних веза и везивања. Женски ликови су медијуми кроз које мушки ликови живе своје животе. Анализом ликова уочава се одсуство породице и недостатак љубави у њиховим животима, што касније утиче на њихове животе и непрекидно трагање за љубављу и припадањем.

Говорећи о друштвеном карактеру, Ерих Фром наводи да под тим појмом подразумева следеће: „суштину карактерне структуре која је заједничка већини чланова исте културе...", насупрот индивидуалном карактеру „...по коме се људи разликују један од другог иако припадају истој култури“ (95). Он наводи да је нездраво друштво: „... 
оно које ствара обострано непријатељство, неповерење, које претвара човека у оруђе употребе и експлоатације за друге, које га лишава осећања свога „ја“, осим ако се не потчини другима или не постане аутомат“ (89-91). Он наводи да друштво може да има обе функције може да допринесе, али може и да онемогући човеков здрав развитак (90). Код Муракамијевих ликова примећујемо да је израженији индивидуални карактер.

О томе говори Зоран Миливојевић, психотерапеут, који емоције - емоционалне реакције и осећања неприхваћености, одбачености и усамљености дефинише на следећи начин:

Неприхваћеност, осећање неприхваћености - „Субјект осећа неприхваћеност када процењује да нека, њему важна особа или група одбија да с њим успостави позитиван однос (639)“.

Одбаченост, осећање одбачености - „Осећање које субјект доживљава у ситуацији када процењује да значајни други прекидају однос с њим због тога што верују да он као биће није ваљан (639)“.

Усамљеност - „Осећање које осећа субјект који процењује да није у могућности да у својој околини контактира с особама које би могле да учествују у његовим жељама и интересовањима. Усамљеност се јавља када недостају важни други и покреће особу на тражење друштва таквих особа (647)“.

\section{Муракамијеви ликови}

Да бисмо могли да објаснимо мотив додира руке и насупрот њему мотив усамљености, неопходно је сагледати и предочити карактеристике Муракамијевих ликова које воде ка уочавању и спознаји наведених мотива.

Када говоримо о Муракамијевим мушким ликовима, оно што примећујемо при анализи њихових особина јесте да њих одликује меланхолија, осећање усамљености и напуштености, отуђености, одбачености и неприлагођености. Они живе своје животе на устаљен начин, препуштени апатији свакодневног живота и уобичајених радњи и навика. Његови мушки ликови делују да су непредузимљиви и с тим у вези помало лењи. Чини нам се да они нису „типични“ 
представници највредније нације на свету, у складу са представом која о њима постоји -неуморним, незаустављивим, упорним и истрајним Јапанцима, чији животни успех се огледа у запослењу у великим корпорацијама. Напротив, животи његових ликова делују једноставно, готово досадно и незанимљиво, којим често ни сами нису задовољни, али се не труде да нешто промене, већ се препуштају навици и познатим околностима, све док их женски ликови, који се појављујући неочекивано и нагло у њиховим животима, не провуку кроз ограде којима су заштитили своје животе.

Анализирајући женске ликове Харукија Муракамија, поново се осврћемо на јапанско друштво, традиционално и савремено, на јапанску породицу, али и на утицај Запада на јапанско друштво, па и на утицај Запада на стваралаштво Харукија Муракамија. Говорећи о таквом утицају, првенствено мислимо на отуђеност припадника модерног друштва, то јест, на осећај неприпадања припадника сопственом друштву. Ми се не бавимо њиховим занимањима. О занимањима, тек понеког од њих, и то мушких ликова, сазнајемо успут, јер се писац не задржава на улози занимања у животу његових мушких ликова, осим ако није у сврху потпунијег описа њихових живота и осећања. О занимањима женских ликова не знамо ништа или тек понешто. Слику коју нам Мураками пружа о својим ликовима заправо је прича о богатству њихових унутрашњих светова, не правећи разлику између мушких и женских ликова. Напротив, Мураками их повезује и пружа описе њихових међусобних односа и утицаја женских ликова на мушке ликове, у циљу давања потпуне слике положаја у ком се налази појединац.

На примеру Муракамијевих ликова уочавамо особине интровертних људи о којима говори Никола Рот у својој књизи Психологија личности, наводећи да интровертне особе карактерише „склоност размишљању, повученост, затвореност, уздржљивост у испољавању емоција, осетљивост на критику, ређи и слабији контакти са људима, окупираност властитим мислима и доживљајима“ (179). Па ипак, иако на примеру мушких ликова уочавамо претходно наведене особине, те особине примећујемо и код неких женских ликова, попут Наоко у роману Норвешка шума, о чему може да посведочи и следећа реченица: „'Овај факултет сам изабрала јер се нико из моје средње 
школе није уписао на њега', рекла је Наоко уз осмех.“(38). Са друге стране, особине екстровертних особа карактерише следеће: „отвореност понашања, спремност на непосредну акцију, слабија осетљивост, реалистичност, вођење рачуна о ситуацијама какве стварно јесу, интересовање за физикалну и социјалну средину у којој живи, лако социјално прилагођавање“ (179). Женски ликови у Муракамијевим романима, као што смо раније навели, „буде“ мушке ликове из њихових уснулих живота и с тим у вези код већине њих уочавамо особине екстровертних особа. Па ипак, неретко особине његових женских ликова чине комбинације екстровертних и интровертних особина. Пример таквог лика несумњиво је Аомаме у роману $1 Q 84$ коју карактерише „отвореност понашања и спремност на непосредну акцију", у ситуацијама упуштања у флерт са старијим мушкарцима и спремност да убије мушкарца насилника, са једне стране, али и „склоност размишљању, повученост, затвореност, уздржљивост у испољавању емоција и ређи и слабији контакти са људима“, са друге стране, када је реч о осећањима која гаји према Тенгу, својој љубави из основне школе.

Муракамијеви ликови душевни спас и блискост често проналазе у странцима, потпуним незнанцима, млађим особама, штавише старији младићи у девојчицама. Један од примера је однос наратора и тринаестогодишње девојчице Јуки у роману Играј играј играј. Помислили бисмо, да је, наизглед, реч о потпуно неспојивим контактима, у којима, међутим, они сами препознају своја тескобна осећања, која потом и ми као посматрачи њихових живота то уочавамо и одагнавамо сумњу у претходно поменуто.

Поредзакључка ка ком нас непрекидно води прича о неумањеним емоцијама између Аомаме и Тенга у роману 1084, можемо се послужити и речима Жилијена Грина, америчког писца, које Ерих Фром наводи у својој књизи, а које говоре о готово неважној улози човека у поређењу са свемиром и о „осећању издвојености и немоћи“, о „стању неизмерног ништавила“, додајући да „усред тог хаоса обмана у који смо главачке бачени постоји нешто што одудара својом истином, а то је - љубав“. (цит. према Fromm 97) Љубав је оно што покреће Тенга и Аомаме, што их одржава јаким, због које не посустају, не одустају, одолевају препрекама и поново проналазе једно друго у држању руку, као и првог пута, двадесет година раније, у основној школи, када су у држању малих руку своју љубав заувек пронашли. 
Алфред Адлер, аустријски лекар, психијатар и оснивач школе индивидуалне психологије говорећи о развитку човековог карактера, као важну улогу у том процесу, наводи и осећање припадања заједници, које долази до изражаја већ у самом детињству - у првим дечијим душевним покретима, нарочито у покретима нежности, у покретима који траже додир (169).

\section{Додир руке и потреба за припадањем}

Читајући и анализирајући Муракамијева дела, приметићемо одсуство нежности, и физичке и вербалне, у животу његових ликова у кругу породице, али и у школи. Будући одбачени, неприхваћени и несхваћени у сопственој породици, они бивају одбачени и у друштву, у следећем кругу људи које срећу током свог одрастања, а то су вршњаци и школа. Они су, међутим, само другачији од већине својих вршњака, а можда и нису. Можда их околности у којима одрастају споља чине другачијим, док су изнутра исти као и друга људска бића која у ствари не желе да буду сама. Они су усамљени и осамљују се јер у томе проналазе своју сигурност, уточиште у ком ће се сакрити и остати неповређени. Они се повлаче, али жуде за додиром, за припадањем и за љубављу, подсвесно, несвесно или пак свесно. У додиру проналазе подршку, разумевање, љубав, истовремено их узвраћајући. Руку пружају и траже је када причају о својим страховима, када треба да саопште нешто што их тишти, о чему не могу лако да причају или први пут икоме говоре.

Додир руке пружа уточиште души, доноси безбрижност и топлину, замењује речи, потенцијално неспретно срочене, или пак лоше изговорене. Додир спаја руке, спаја душе, одагнава све страхове и умањује патњу. Додир руке у Муракамијевим романима запажамо у различитим односима, између различитих особа. Наведимо примере:

У роману $1 Q 84$ старица-газдарица, са којом Аомаме сарађује у заштити немоћних жена, у тренутку када Аомаме прича о својој другарици из основне школе, узима је за руку. У роману Играј играј играј, Јукина мајка, Аме, која својој кћерки није посвећена, због чега је кћерка не осуђује, комуникацију остварује додиром. Јуки свом 
пријатељу наратору пружа подршку узимајући га својом, како он каже, малом и топлом руком, за руку, у чијем додиру он осећа „... оживљавање успомена из прошлости и ништа више“ (358). Истовремено, и он њу узима за руку када је охрабрује и говори јој да не брине због одбачености у школи и страхова због неразумевања околине и различитости која није њена мана, већ је краси и чини посебном.

Протагониста романа Јужно од гранище, западно од сунца и као одрастао човек осећа додир Шимамотине руке када су били деца и који је кратко трајао, али је њега зачарао: „И сада се јасно сећам додира њене руке. Разликовао се од свих других додира које сам тада познавао, а и од оних које сам касније упознао." (17-18).

Сара, Цукуруова девојка, у роману Безбојни Цукуру Тазаки и његове године ходочашћа додиром своје руке охрабрује Цукуруа приликом доношења одлука или страховања у вези са њиховим односом у будућности (189).

Сумире, у роману Спутник љубав, била је свесна лепоте свога оца и себе која је својим изгледом била у његовој сенци, али ју је њена пријатељица Мју охрабрила следећим речима, истовремено нежно додирујући њену руку: „'Па, ти си веома згодна. Чак ништа мање од твог оца', рекла је Мју.“ (25).

У роману 1Q84, седамнаестогодишња Фукаери пружа тридесетогодишњем Тенгу подршку држећи га за руку. Претпоставка је да другима делују као момак и девојка који се воле, али додир њене руке је прецизан, нема осећаја љубави према супротном полу: „Та девојка можда путем додира својих прстију и длана покушава да размени неке информације које не успева да саопшти речима“ (151). У овом случају таква улога њене руке је довољна и баш онаква каква у њиховом односу и треба да буде.

Усамљеност у романима Харукија Муракамија

Као други важан појам, који уочавамо у романима Харукија Муракамија, издваја се појам усамљености. Појам усамљености посредно је описан кроз опис мотива додира руке и потребе за припадањем. Да бисмо се надовезали на тежњу ка припадањем и додиром као потврдом припадања, подршке и постојања, послужићемо се термином „срдачне руке“ о којем у књизи Усамљена гомила говори Дејвид Рисман, амерички социолог, описујући америчко друштво 
након Другог светског рата, чији се описи могу применити на друштво данашњице уопште, у времену отуђења, осаме и усамљености и ужурбаности које модерно друштво доноси. Говорећи о „срдачној руци“, Рисман жели да укаже на промене до којих у друштву долази. (294 - 295) Људи се удаљавају једни од других, све је обезличено, мале радње замењене су огромним продавницама у којима нема усредсређених и срдачних продавачица, не постоји посвећеност, већ је све засновано на аутоматима, брзој, поједностављеној услузи и односу. Људи су у гомили, окружени су једни другима, али су усамљени. Такву слику увиђамо и у романима Харукија Муракамија - обезличеност модерног друштва у коме „живе“ његови ликови. Потреба за додиром руке брише усамљеност коју осећају, понекад само краткотрајно, а понекад он остаје трајан и снажан у њиховом сећању.

\section{Закључак}

Модеран живот, материјална осигураност и сигурност, као водеће одлике модерног друштва, истовремено су одлике друштвеног суноврата, јер упркос сигурности коју такав начин живота пружа, он са собом доноси и емотивну празнину.

У роману Спутник љубав, код сва три лика, Сумире, Мју и наратора, примећујемо отуђеност. Иако Сумире уме да се осами по неколико сати у канцеларији, не причајући ни са ким, Мју воли да путује сама, а он да проводи летње распусте сам, жудња за љубављу и самим тим осећаја припадања некоме, код све троје, у свету отуђености који је такав постао или су га они таквим учинили, као своје привидно нормално окружење, постоји. Надовезујући се на претходну мисао, додали бисмо да се потреба за припадањем не огледа у топлини било чијег додира, већ у припадању особи поред које се они осећају пријатно и у којој проналазе део себе, независно од тога да ли је реч о недавно упознатој особи или о пријатељу из школских дана. Тиме стичу осећај да нису сами у свету који нарушава њихов идентитет и доводи до отуђења.

Кроз ликове које Харуки Мураками ствара, уочавамо проблеме са којима се не суочава само савремено јапанско друштво. Њих одликују особине које карактеришу човека данашњице уопште, али 
истовремено указује на борбу појединца, као малог дела великог система, осећајући да му не припада. О положају човека као индивидуе неснађене у друштву чији је припадник, али се тако не осећа, не говори само Харуки Мураками. Ова тема је и раније у књижевности обрађивана и несумњиво ће и надаље представљати тему о којој ће се писати, читати и која ће се анализирати. С тим у вези, проблеми са којима се Муракамијев лик суочава, представља савремену и свевремену тему, која не познаје географске, националне границе, нити странице једног романа. О њој су, видели смо раније, писали и Кјеркегор, Жилијен Грин, али и Франц Кафка, у роману Процес, описујући немоћ појединца у систему који управља његовим животом или, пак, Харукијев презимењак и савременик, Рју Мураками у романима Караоке страве и У мисо супи.

Ерих Фром у књизи Бекство од слободе каже за усамљеност следеће: „... човек, стичући све више слободу у смислу издизања из првобитног јединства са човеком и природом, и постајући све више „појединац“, нема другог избора до сједињења са светом у спонтаности љубави и производног рада, или, пак, тражења некакве безбедности у везама са светом које разарају људску слободу и интегритет појединачне личности“ (21). Он такође додаје и следеће за појединца: „....може да живи међу људима а да га ипак савлада осећање крајње издвојености..." (19). Осим, могли бисмо да додамо, уколико у додиру руке не осети да није усамљен и да, ипак, некоме припада.

\section{Литература}

Адлер, Алфред. Познавање човека. 3. изд. Нови Сад: Матица Српска, 1990. Print. Фром, Ерих. Здраво друштво. Београд: Рад, 1980. Print.

Fromm, Erich. Bekstvo od slobode. Djela u 12 svezaka. Zagreb: Naprijed, Nolit, August Cesarec, 1984. Print.

Јунг, Карл Густав. Човек и његови симболи. Београд: Народна књига - Алфа, 1996. Print. Миливојевић, Зоран. Емоције: Психотерапија и разумевање емоција. 2. проширено и допуњено издање Нови Сад: Прометеј, 1999. Print.

Мураками, Харуки. Јужно од границе, западно од сунца. Превела с јапанског Наташа Томић. Београд: Геопоетика, 2011. Print.

Мураками, Харуки. 1Q84: април-јун. Књ. 1. Превела с јапанског Наташа Томић. 2. изд. Београд: Геопоетика, 2011. Print. 
Мураками, Харуки. Норвешка шума. Превела с јапанског Наташа Томић. 3. изд. Београд: Геопоетика, 2013. Print

Мураками, Харуки. Спутник љьбав. Превела с јапанског Дивна Томић. 2. изд. Београд: Геопоетика, 2013. Print.

Мураками, Харуки. Безбојни Цукуру Тазаки и његове године ходочашћа. Превела с јапанског Наташа Томић. Београд: Геопоетика, 2013. Print.

Мураками, Харуки. Играј играј играј. Превела с јапанског Дивна Томић. 3. изд. Београд: Геопоетика, 2013. Print.

Рисман, Дејвид, Глејзер Нејтен, и Дени Руел. Усамљена гомила: студија о промени америчког карактера. Нови Сад: Библиотека Архипелаг, Mediterran Publishing, 2007. Print.

Рот, Никола. Психологија личности. 14. изд. Београд: Завод за уџбенике и наставна средства, 1988. Print.

"Questions for Murakami about Kafka on the Shore." Haruki Murakami. Penguin Random House, Web. 14. Sept. 2015.

Wray, John. "Haruki Murakami, The Art of Fiction No. 182." The Paris Review. Summer 2004. Web. 21. Aug. 2013.

\section{Milica Obrenović}

University of Belgrade

Faculty of Philology

\section{THE NEED FOR BELONGING AND TOUCH OF A HAND AS OPPOSED TO THE LONELINESS IN THE NOVELS OF HARUKI MURAKAMI}

\section{Summary}

This paper analyzes characters of Haruki Murakami who live in contemporary, modern Japanese society, often alienated from each other. The theme is timeless. The analysis of motives of a need for belonging, touch and loneliness, crosses geographical, national and cultural borders, but also the pages of a novel, because mentioned motives represent the characteristics of each person, with the same inner needs and fears, wherever and whenever he lived.

Most of the characters created by Murakami often spend time in loneliness, feeling pretty safe, almost satisified with themselves in companionship. However, with a further and deeper analysis of both male and female characters, we note that 
they secretly yearn for closeness and belonging to someone. Achieving closeness with another person, they find a part of themselves.

Regardless of whether it is a male or female character, Murakami indirectly deals with the aspect of relationships and reassociating with people around us, but also with ourselves. He tells us about the monotony of modern society, awaking its existence in a way that preoccupies his characters and alienates them from one another, but also from themselves.

Key words: belonging, touch of a hand, loneliness, closeness, support, understanding, safety. 